\title{
An Analysis of Double Impacts of Rural Clan in New Rural Construction
}

\author{
Na Ning \\ College of Politics, Sichuan Agricultural University \\ No. 211, Huimin Road, Wenjiang District, Chengdu 611130, Sichuan, China \\ E-mail: ningna826@126.com
}

Received: August 30, 2011

Accepted: October 16, $2011 \quad$ Published: March 1, 2012

doi:10.5539/ass.v8n3p118

URL: http://dx.doi.org/10.5539/ass.v8n3p118

\begin{abstract}
As a part of traditional Chinese culture, clan has both positive and negative impacts on the construction of new socialist countryside. On the one hand, it has definite positive impacts on protecting farmers' interests, satisfying the psychological and emotional needs of farmers, and facilitating the construction of new socialist countryside. On the other hand, due to their narrow-minded interests and backward thoughts, it hinders our process of building democratic and law-based construction in rural areas and, furthermore, it poses a negative impact on the harmonious construction of new socialist countryside. Therefore, it is necessary to start with the regiment construction, construction of rule of law, cultural construction, construction of thoughts and so on to dispel the social space for the survival and development of clan and finally realize the disintegration and extinction of clan in the building of new socialist countryside.
\end{abstract}

Keywords: New countryside construction, Clan, Double impacts

Clan, which is also termed as family, refers to the family association linked by the blood relationship. Clan has a long history in China. It can be said that in entire traditional society of China, the patriarchal clan system and the national law are complementary with each other, clan power and political power jointly govern, and blood relationship and geopolitics are closely connected with each other, during which the power of clan is extension and supplement of the national power. Hence, the clan culture is an important nature of Chinese traditional political culture. Since the 20th Century, the clan has been considered to be feudal remnants and negative and backward and has been negated and stroke down. However, in the recent years, along with the deepening of economic system reform in rural areas, "rejuvenation" to a certain extent has appeared in the local clan organizations, which has non-negligible impacts on the current construction of new socialist countryside.

\section{Positive Impacts of Clan on New Countryside Construction}

Mr. Francis Hsu ever said that: "If people form a group of their own in one way rather than others, and this particular group formation way is passed on from generation to generation for many centuries, and, also, there is no significant change or even any resistance against the change, then it must be admitted that those people related with formation of the group must have discovered some sufficiency and satisfaction that can't be found in other group formation ways." (Francis Hsu, 1990, 61) As a sort of social group or social organization, the existence of clan has its profound historical and cultural origins, and its extinction would have to go through a relatively long historical process. To some extent, in the process of building new socialist countryside, the objective existence of the clan has also played a positive role.

In the first place, to certain extent, clan helps to maintain a stable and harmonious public order in new rural areas. In the construction of new socialist countryside, harmony and stability are the first prerequisite, while harmony and stability call for certain authority and order. At the current significant social transition stage, due to the fact that the political system of villager autonomy needs a gradual improvement and progradation process, democracy and rule of law still have not become a concept of order that the villagers generally follow. Mr Fei Xiaotong pointed out in the "Xiangtu Zhongguo" that rural China is a society which governs its people with formality which takes the family as the center, forms the pattern of difference sequence, and obeys governance 
by the elderly. Therefore, the role of authority and position which is based on the age and seniority in governance of a village can not be ignored. In the actual life, clan often plays a greater and more positive role than village-level regime organizations in mediating villagers, maintaining social public order and especially human relations order at a moral level. It is usually the authoritative elderly in a clan who come forward to mediate some family affairs, such as, breaking up the family and living apart, separating the family property, disputes among brothers and contradictions between uncles and nephews. Even for some significant disputes which have to be resolved by village cadres, authoritative elderly in the clan are also often invited to assist the mediation work. In the meantime, the clan can also play a positive role in restraining some of the "immoral" behaviors of villagers and in condemning and moralizing those villagers with "corrupt conduct" and "moral bankruptcy". Therefore, in the current rural governance, to a certain extent, the clan plays a role as the buffer and resolving device of conflicts, and fills in the management vacancy in the village governance, which effectively avoids the anomie and disorder of the rural relationship in the social transition.

In the second place, to a certain extent, clan is helpful to protect the interests of farmers. The urban-rural dualistic system with a long history has made the interests of the vast majority of farmers unable to get effective protection, which offers space for existence and functioning of the clan. From the point view of politics, clan provides a new channel for the protection and reaction of the interests of farmers. In the rural areas in which villager autonomy is the principal political system, although villagers have relatively automatic rights, but the voice of an individual farmer is often too puny, while the voice can be magnified through the clan and the issues might be taken seriously. Meanwhile, the integrity of clan has also played a positive role in protecting the interests of its members and fighting against any illegal infringement from executive power. From the point view of economy, clan provides a solid and reliable foundation for the internal cooperation within the clan. Over the years, the collaboration consciousness and credit mechanism within the clan have been the obvious characteristics of the clan. And it is exactly this collaboration and credit which is built on the basis of blood relationship that make the clan have a much more reliable relationship network than other society organizations, which is, to some extent, equivalent to an economic resource in the contemporary society, having great facilitating effects on all varieties of economic activities either within the clan members or outside the clan.

In the third place, clan has also enriched the spiritual and cultural life of villagers, and has met with public emotional and psychological needs of villagers. In the current social transition process, the vast majority of farmers are often in a weak position whose benefits are likely to be sacrificed and whose spirit can not find the sustenance, while existence of clan provides a home to return for people to search for stability and sustenance. Furthermore, the revival of clan itself is release of the psychological and emotional energy of people that have long been repressed and is reflection of the fear and guarding psychology of people in the social change and of the attitude to seek for historical stability feeling. (Gong Zhiwei, 2006) In the social life, on one hand, the varieties of cultural activities which take clan as a unit enable the villagers to gather together to reinforce relations, which has not only enriched the spiritual and cultural life of the farmers, but also has activated the dull atmosphere in rural areas. On the other hand, clan also provides some social welfare and security guarantee for the villagers. For a long time, clan has played an important role in such social affairs as building bridges and paving roads, poverty alleviation and social relief, which not only provides a kind of value support for villagers, but also greatly satisfies the profound need of villagers for their own sense of history and belonging.

\section{Negative Impacts of Clan on New Countryside Construction}

As has been mentioned above, objective existence of clan has certain positive effects on easing social conflicts, stabilizing the popular feelings, improving the self-governance capacity of rural farmers and promoting social harmony and stability. Nonetheless, as a result of limitations of the traditional consciousness of clan and current democratic and cultural level of farmers as well as the strong standard concept of clan, it is unavoidable that the clan comes into conflict with the democratic autonomy of villagers, and even more serious consequences may be caused.

In the first place, clan affects democratic election and destructs democratic autonomy of villagers. The system of community level self-governance is carried out in Chinese rural areas and village committee is the automatic organization for rural grass-root public. According to regulations of "Law of Organization of Village Committee", members and the director of the village committee are directly elected by villagers. In view of this, in the process of electing the village cadres, some clans bend the law for personal gains and engage in fraud for their own interests, interfere, disturb and even manipulate the election process in the hope of electing the "appropriate" candidate who can mostly represent their interests. However, at the same time, when villagers conduct the election process, they also often determine the election candidate by taking into consideration of the blood 
relationship, but not taking into account of the capacity and popular trust of the candidate. Thus, the result of the election is usually that the predominant clan gains the power of manipulation on politics of the village. To some extent, village level organizations have become an outcome for clans to balance their rights and become a clan organization that "are wrapped below a lawful appearance". As a matter of fact, clan power and regime power are consistent.

In the second place, clan affects democratic management and weakens authority of village level organizations. Since village officials who are elected in the background of the above factors are themselves placed in the network of clan, they are the "mouthpiece" of the interests of the clan. Leaving aside whether they have enough ability to be qualified for the post, they have to take into consideration of the enormous clan relationship and influences in dealing with all sorts of public affairs and finally enable the village committee to become a private body to protect the interests of the clan. Besides, even if the delegates of the villagers are elected via democratic election, when they deal with public affairs, it is unavoidable that these village officials have the mind of "holding back from taking actions" as the background of the clan often becomes an important factor in influencing the working method and pattern as well as power limits of village officials. In this way, authority and function of the village committee will be seriously affected and villager autonomy may also perform practically no function at all and become nothing more than a meaningless term.

In the third place, clan hinders progress of construction of rule of law in rural areas. In the extensive rural areas, there exist generally the problems of imperfect rules and regulations and that rural villagers have rules which they don't follow. Among the village organizations in which clan authority manipulates the village politics, the phenomenon is also common that clan rules and regulations take the place of village rules and regulations or villager autonomy regulations. In some areas, authority of clan has become one of private property which parallels with the executive power and judicial power of the nation. What's more, when interests of clan come into conflict with the national and collective interests, usually implementation of the national policies and guidelines may be impeded. The clan members may even resort to such illegal means as attacking the government and resisting against execution of official duties with violence. In addition, the dominant standard concept of clan is also likely to give rise to excessive intensified identity of clan. Once a member of the clan comes into conflict with an outsider, the conflict is usually escalated to one which is concerned with reputation of the clan, which may intensify the contradiction and may seriously affect construction of a harmonious village. Furthermore, due to the traditional thought of "it is the fault of the father, if his son is not well-educated", clan has always advocated that "domestic shame should not be made public". This thought greatly encourages illegal resolution of disputes and going revenge and may even give rise to crime of harboring criminals. This phenomenon that power of law make place for power of clan and rule of human is greater than rule of law seriously runs counter to the spirit of modern democratic rule of law and hinders progress of socialist construction of rule of law.

In the fourth place, clan intensifies the democratic consciousness of villagers. Clan remodels the cultural environment of psychological control by the traditional clan over individuals by means of intensifying constraint, administration and control over the clan members through a variety of activities and clan rules and regulations, etc. The common farmers with the background of clan culture just have such a "public will" that is nothing more than the will of the authoritative people within the clan or will of "a large majority of people" and they just silently keep the will or expression of will that they themselves can't have or need not to have in the "authority". In participation in various social affairs, they only consider themselves a member in the clan, but are unaware that they are one of the citizens of the country. In this way, the citizens become the members of the clan and scope of "democracy" is merely limited to the scope of the clan. Likewise, although the relationship of mutual help and assistance and mutual dependence within the clan is of great importance to strengthen people's feeling of security and feeling of belongings, it also restrains functioning of people's independence, creativity and enthusiasm, destructing freedom of individualism and hinders realization of individual self-value.

In the fifth place, the clan affects rural production and operation activities and spiritual and civilization construction. In those places where clan organizations have great power, the clan members set up economic complex among those with the same surname and same clan, protect the economic interests of the clan and the big family and even hold illegal operational activities to interfere in development of the collective economy and the normal economic order. In those places where the power of clan is power, feudal etiquette and customs resurge, pedigree of the clan is repaired, ancestral temple is re-constructed and ancestral graves are constructed successively one after another, which not only adds to burden of farmers, but also affects seriously rural spiritual and civilization construction. 


\section{Countermeasures to Eliminate Negative Impacts of the Clan on the New Countryside Construction}

The double impacts of clan on the new socialist countryside construction requires us to dialectically treat with the historical and cultural phenomenon of clan. At the time when we bring the positive impacts of clan on the new countryside construction into the track of standardization, institutionalization and legalization, w should also eliminate its negative impacts on the new countryside construction and finally make gradually disintegrated and die away in the process of construction of the new socialist countryside.

Firstly, to reinforce construction of rural grass-root regime. The relationship of one waning and the other waxing exists between power of clan and perfection degree of rural grass-root organizations and construction of rural grass-root regime. It is true that extreme development of clan power in some places are various, but considering the main reasons, this also has something to do with the weakness and slackness of rural party organization and weakness and feebleness of grass-root regime and with incomplete growth of rural grass-root public organization. Hence, it is necessary to strengthen construction of village level organization that is centered with the village party branch. First of all, it is necessary to make a good job of construction of rural grass-root party branch, especially selection and allocation of village party branch secretary and establish the leadership and central position of the party in grass-root organization. Then, it is necessary to strengthen construction of village level public self-governance organization. We have to exclude interference of clan power and elect the village cadres who have perfect business ability, strong sense of responsibility and dedication to the collective affairs. Hence, the superior organization has to specially strengthen management and direction. Never is irresolution allowed for those village cadres who are wild about clan activities who have to be dismissed and replaced. Timely adjustment has to be made on the "party branch committee and village committee" that are unlikely to resist power of clan. As for those villages where clan activities prevail and village cadres who are elected by the villagers themselves are unlikely to do their work, the party committee of the higher level has to accredit qualified cadres to take the office or send a working team to vigorously strengthen construction of grass-root public security committee and conciliation committee, allocate qualified and sufficient personnel, realize their treatment, give full play to their function of the first line of defense in constructing a harmonious village and restrain spreading and expanding of clan power.

Secondly, to strengthen rural legal construction. The primary thing to do is to tighten up the legal system. It has been a long time that the actual enforcement of law is always passive as a result of lack of definite legal provisions with strong operability in dealing with the problem of clan. It is of great urgency that the position of clan has to be confirmed from the perspective of law, for which we can refer to policies and regulations concerned with religion, league, march and publication, etc., to carry out a scientific clan management method. Then, it is necessary to severely attack illegal activities of clan. The government section and judicial organ have to execute resolute attack on such illegal actions as fighting with weapon, illegal election, riding roughshod over villagers and fabrication of disputes, etc. "Clan head", "village hegemonist", "witch", and "wizard" have to be brought to justice who take advantage of clan power to threaten the security of the society and propagandize feudal superstition so as to form a great atmosphere in which the whole society gather together to resist illegal activities of clan.

Thirdly, to vigorously develop rural collective economy. Closeness and backwardness is the social source which breeds clan power. Rural collective economy is the material foundation to construct a harmonious village. Only if the economic strength of rural collective economic organizations is strengthened, can they bring tangible benefits to farmers, do good to them, actually reduce their burden and help them increase their income and wealth. At the same time, economic development can also add to social public resources, drive development of a series of social public careers, such as, cultural education, scientific sanitation and social security and enable farmers to live and work in peace and contentment. It is proved by the fact that those villages in which collective economy is better constructed have a grass-root organization with strong appealing force, cohesive force, public trust force and fighting force and it is natural that clan power has no social and cultural space for survival and development.

Fourthly, to reinforce rural spiritual and civilization construction and construct modern village culture. The concept of clan falls within the scope of ideology, which should not be eliminated simply via administrative means or external compulsion. Only reinforcement of rural spiritual and civilization construction and improvement of farmers' ideological and cultural quality can build a modern village culture that corresponds with the harmonious village. In the process of reinforcing rural spiritual and civilization construction, we have to combine inheritance of excellent historical and cultural tradition together with promotion of socialist culture development, and, meanwhile, vigorously carry forward family virtue, social public virtue and occupational virtue and focus on enhancing the scientific and cultural quality and ideological and moral quality of villagers. 
On one hand, it is necessary to propagandize and carry forward the positive content in Chinese traditional culture that complies with the requirement of the times and is helpful for interpersonal harmony and human relation order, such as, respecting the aged and taking good care of children, modest salute to others and honesty and trustworthiness, etc. On the other hand, we ought to make use of traditional patterns which are full of national and local features and which villagers are delighted to hear and see to propagandize advanced socialist culture. For example, establishment of the following public organizations well direct transition from traditional clan culture to the modern village culture with democratic rule of law, build a peaceful, positive, healthy, civilized, effective and harmonious atmosphere and offer strong and powerful spiritual support for construction of the new harmonious socialist countryside: appraisal activities of civilization village and civilization household, "professional farmers' association", "standing council of villagers" delegate" and "woman association to prohibit gambling", etc.

To sum up, as part of Chinese traditional culture, existence, development and influences of clan culture have the social and historical origin. In the process of building the new socialist countryside, it is not only necessary to take into consideration of the objective reality of its existence and provide scientific direction and standardization with appropriate steps and plans, but also necessary to pay special attention to its negative impacts, and speed up the pace of construction of the new socialist country with the aim to finally realize disintegration and extinction of clan culture in the process of construction of the rural modernization.

\section{References}

Chen, Deshun. (2005). Review of Studies on the Issue of Rural Clan. Journal of Yunnan Nationalities University, July.

Francis Hsu. (1990). Clan, Caste and Club, translated by Xue, Gang. Beijing: Hua Xia Press, p.61.

Gong, Zhiwei. (2006). Harmony and Conflict: Reading of Relationship between Clan Revival and Rural Management in the Social Change. Theory and Reform, 1.

Zhang, Liu \& Huang, Rui. (2006). Influence of Rural Clans Power on Construction of Grassroots Party Organizations and Countermeasures. Guangxi Social Sciences, 1.

Zhou, Daming. (2003). Contemporary Clans and Society in South China. Harbin: Heilongjiang People's Publishing House. 